\title{
C $\begin{array}{llll}\text { A } & \text { T } & \text { V }\end{array}$
}

\section{1. ま がき}

同軸ケーブルを使って，テレビ信号を各家庭に送り届 けるととは，米国のみならず，わが国ですテレビ放送の 開始後間むなく試みられた. その後, テレビ電波の届か ない地域において共同㯖視設備として, 僻地を中心に多 くの施設が作られて来た．しかし近年に至って，乙のケ ーブルによる伝送設備が非常に広帯域の信号を伝送しう る技術的可能性を持っているととに着目し，ひとりテレ ビの再送信のみならず，多種多様なサービスを提供する 基本的能力を有する伝送手段であるとして，CATVな る言葉の下に，にわかに脚光を浴びるようになった.

\section{2. 技 術基 準}

\section{1 わが国の技術基準}

前記のような情勢の下に，都市においても有線による テレビ伝送を試みる動きが現われ，乙れに関連して 1969 年に有線テレビ関連の改正法案が初めて国会に提出され たが，乙れは廃棄となった，その後，再び 1971 年の通 常国会に“有線テレビジョン放送法案”が提出され，本 年 6 月に成立した.

同法案では有線テレビ放送施設の許可条件のひとつと して，“郵政省令で定める技術上の条件に適合するあの であること”と定められており，ここにわが国であ有線 テレビの技術基準なる考え方が浮び上って来た.

このような状況の下に，1969 年，電波技術協会が音 頭をとり，関係団体に呼びかけて “有線テレビジョン技 術調査委員会” が作られ，都市の有線テレビ施設に要求 される性能規格の調査を開始した. その結果, 1969 年 12 月に第 1 次の報告書 ${ }^{1)}$ が作成され, その中に有線テレ ビ施設に要求される性能規格が報告されている．この值 は以後, 施設, 機器の設計製作を行なうに当ってひとつ の目安を与えたととになり，わが国の有線テレビの発達
NHK 総合技術研究所 安 東 平一郎

告が作成されるとととなろう(1972 年3月現在).

性能規格についてはまだ確定していない項目むあるが ほぼ表 1 に示すような值となるもようである.

\section{2 海外の技術基準}

海外においても CATV に対する技術基準作成の動き はあり，1971 年3月には IEC の事務局案 ${ }^{4)}$ が発表され

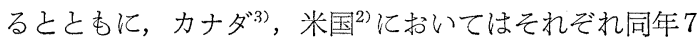
月，1972 年 3 月末より技術基準が実際に適用されるこ ととなった．乙れらの值も表1に併記してある.

\section{3 ケーブル内の周波数配列}

上記有線テレビジョン技術調查委員会では, 性能規格 を論議するに当たり，さらにテレビ放送周波数帯以外の 周波数帯を使ってテレビ信号を伝送する場合に，推奖す ベきチャネル配列をむ併せて検討した，その結果，現在 市販されている受像機を用いて受像すると仮定すると， 図 1 に示すような割り当てが最す望ましいとの結論が得 られた。

\section{3. 国内の動き}

\section{1 委員会関係}

後述のように，大都市に扔いて現実に CATV が作ら れるようになるととむに，CATV を調查する委員会が 各方面に作られ，多くの論議がなされた，その中で代表 的なあの 1 〜を紹介する.

(1) CCIS 調查会 ${ }^{5)}$

郵政省が中心となり，1971 年 9 月に結成された委員 会で, CCIS (Coaxial Cable Information System) に対 する CATV の可能性の調查検討を行なっている. たと えば同調査会は 1971 年 11 月に需要調査を行なったが その結果は，表 2 のおりである。乙の調査は, 調查区 域を大都市，農村等，6地域に分類し，2,800 世帯を対 象として行なったものである.

（2）地域情報化システム調査委員会

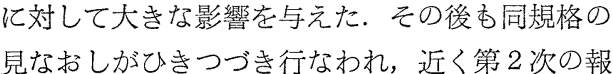

"CATV" by Heiichiro Ando (NHK Technical Research Laboratories, Tokyo)

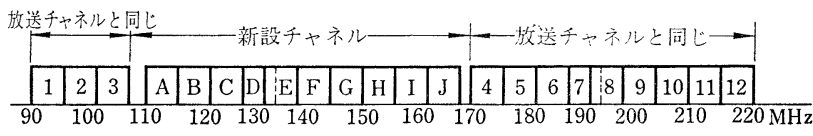

図 1 CATV 内のチャネル割当て案 
表 $1 \mathrm{CATV}$ の技術基準

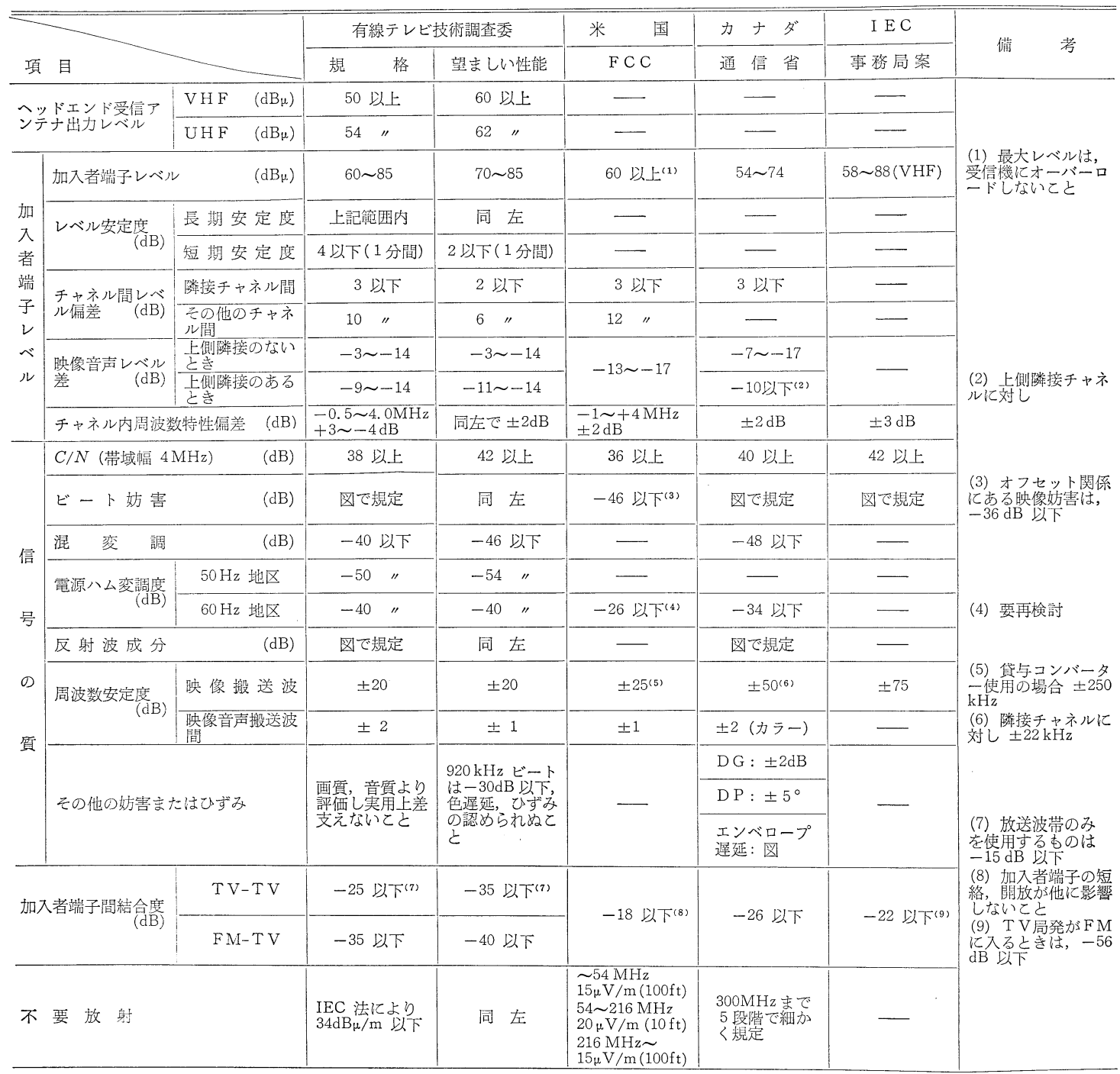

表 2 地域別，サービス段階別加入希望世带率

(単位：\%)

\begin{tabular}{|c|c|c|c|c|c|c|c|c|c|c|c|c|c|c|c|c|c|c|}
\hline \multirow[b]{2}{*}{ 悝 } & \multicolumn{3}{|c|}{$\begin{array}{l}\text { (1)地元再送信サー } \\
\text { ビス }\end{array}$} & \multicolumn{3}{|c|}{$\begin{array}{l}\text { (2) 区域外再送信サ } \\
\text { ビス }\end{array}$} & \multicolumn{3}{|c|}{$\begin{array}{c}\text { (3)自動反復サービ } \\
\end{array}$} & \multicolumn{4}{|c|}{ (4)自主番組サービス } & \multicolumn{4}{|c|}{$\begin{array}{l}\text { (5)リクエスト番組サー } \\
\text { ビス }\end{array}$} & \multirow{2}{*}{$\begin{array}{l}\text { (6)個別情報サ } \\
\text {-ビス } \\
\text { 㫷本料金 } 1,000 \\
\text { 使度数料 } \\
\text { 金 }\end{array}$} \\
\hline & 500 円 & 300円 & 計 & 500円 & $300 円$ & 計 & $500 \mathrm{PJ}$ & 300円 & 計 & $\begin{array}{r}1,000 \\
\text { 円 } \\
\end{array}$ & 700円 & 500円 & 計 & $\begin{array}{r}1,000 \\
\text { P }\end{array}$ & 700円 & 500円 & 計 & \\
\hline $\begin{array}{l}\text { 大都市中心部地 } \\
\text { 域 }\end{array}$ & $\begin{array}{r}(20.4) \\
5.5 \\
\end{array}$ & $\left(\begin{array}{c}(17.1) \\
4.5\end{array}\right.$ & $|(37.5)|$ & - & - & - & 17.5 & 12.2 & 29.7 & 7.1 & 0.1 & 0.0 & 27.2 & 9.9 & 0.1 & 21.5 & 31.5 & 15.9 \\
\hline $\begin{array}{l}\text { 都市多チャネル } \\
\text { 地域 }\end{array}$ & $\begin{array}{r}(15.9) \\
2.8 \\
\end{array}$ & $\begin{array}{c}(13.6) \\
2.4 \\
\end{array}$ & $\begin{array}{r}(29.5) \\
5.2 \\
\end{array}$ & - & - & - & 13.1 & 12.4 & 5.5 & 4.8 & 1.2 & 8.3 & 4.3 & 8.4 & 1.6 & 3.1 & 33.1 & 12.7 \\
\hline 域 & 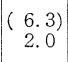 & $\begin{array}{l}(8.4) \\
2.6\end{array}$ & $\begin{array}{r}(14.7) \\
4.6\end{array}$ & - & - & - & 14.5 & 12.7 & 27.3 & 4. 2 & 1.3 & 8.7 & 24.2 & 6.4 & 1.5 & 20.4 & 28.4 & 8.2 \\
\hline $\begin{array}{l}\text { 都书少チャネル } \\
\text { 地域 }\end{array}$ & $\begin{array}{c}(15.8) \\
2.1\end{array}$ & $\begin{array}{c}(15.8) \\
2.1 \\
\end{array}$ & $\begin{array}{c}(31.6) \\
4.2 \\
\end{array}$ & 23.7 & 24.2 & 47.9 & 6.1 & 24.6 & 50.7 & 5.6 & 1.6 & 1 & 36.4 & 9.9 & 1.6 & 27.7 & 39.2 & 15. \\
\hline $\begin{array}{l}\text { 農村多チャネル } \\
\text { 地域 }\end{array}$ & $\begin{array}{r}(31.3) \\
2.1 \\
\end{array}$ & $\left\{\begin{array}{l}6.3) \\
0.4\end{array}\right.$ & $\begin{array}{r}(37.5) \\
2.5\end{array}$ & 28.5 & 8.8 & 37.2 & 38.9 & 11.3 & 50.2 & 19.2 & 1.7 & 24.3 & 45.2 & 25.1 & 0.4 & 5.9 & 51.5 & 5.9 \\
\hline $\begin{array}{l}\text { 農村少チャネル } \\
\text { 地域 }\end{array}$ & $\begin{array}{r}(25.0) \\
2.8\end{array}$ & $\begin{array}{c}(16.7) \\
1.9\end{array}$ & $\begin{array}{r}(41.7) \\
4.7\end{array}$ & 40.1 & 14.6 & 54.7 & 45.8 & 13.2 & 59.0 & .4 & 0.5 & .2 & 50.0 & 16.0 & 0.5 & 34.9 & 51.4 & 18.4 \\
\hline
\end{tabular}

（注）（）内は，受信不良世帯における地元再送信サービスの加入希望率 (CCIS 調査会調べ) 


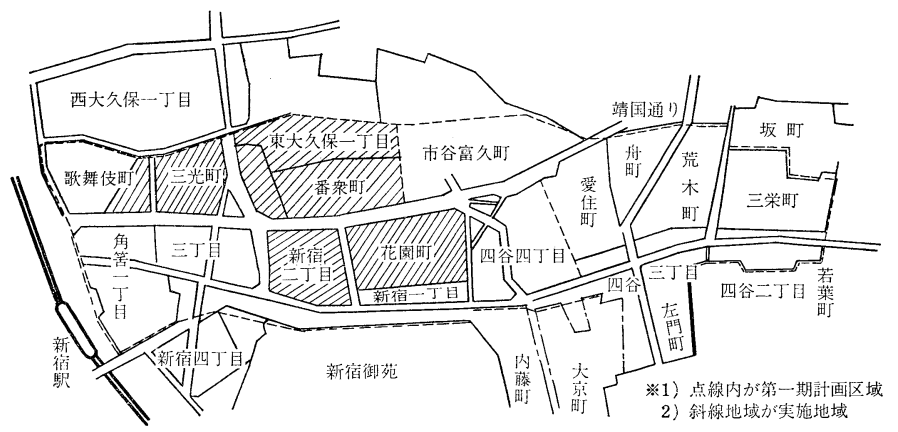

図 2 東京ケーブルビジョンのサービスエリア

通産省加らの補助金を基として日本電子工業振興協会 が各方面の専門家を集めて行なっている委員会であって CATV 等の発達がもたらす地域情報社会の全体像を明 らかにしようとするあのである。同委員会では 1971 年 12 月中間報告として, 情報を適正価格で購入する習慣 の確立, 実験タウンにおけるモデルプロジェクトの推進 など， 7 項目の提言を行なっている.

\section{2 システムの現状}

1969 年頃より大都市に执いて CATV を設けようとす る動きが活発となり, 1970 年 1 月には関係機関の出資に より“財団法人東京ケーブルビジョン”が設立された. 同社は, 都市難視地区である新宿にまず施設を設けるこ ととしたが，なにぶんにもわが国最初の大都市 CATV
形でああり，技術的設計，道路や電柱の使 用許可を得るととなど，多くの工事上の難 問をかかえ，最初期待されたほど急速には サービス規模は拡大していない。しかし， 1970 年末には新宿で, 1972 年 2 月には池 袋地区でサービスを開始した. 1972 年 2 月 末の線路長約 $17 \mathrm{~km}$, 有効タップ数 1172 , 加入者数 543 セットである ${ }^{6}$.

上記の東京ケーブルビジョンにひきつづ き大阪, 福岡, 名古屋等にあ同様な組識が 作られるとと屯に, 北海道, 新潟等, 各地に おいても CATV 協議会が結成されている，てのうち大 阪の京阪神ケーブルビジョンの建設した鈴蘭台地区は， 大阪民間放送の難視地区のととむあり加入者数は 1,500 台に及んでいる.

一方，NHK では従来より僻地の共同受信設備に対し ては補助を行なって来たが，1969年より基幹部分につい て負担して，積極的に共同受信設借を建設している．そ の施設数は毎年数百施設以上に及び，とこに用いられる 機器の規格性能は, わが国の共同受信設備の標準となっ ている，乙れらの設備の特性は，前記の有線テレビジョ ン技術調査委員会が 1969 年 12 月に発表した值に準じ ている.

この他にも，比較的規模の大きい設備としては，地域

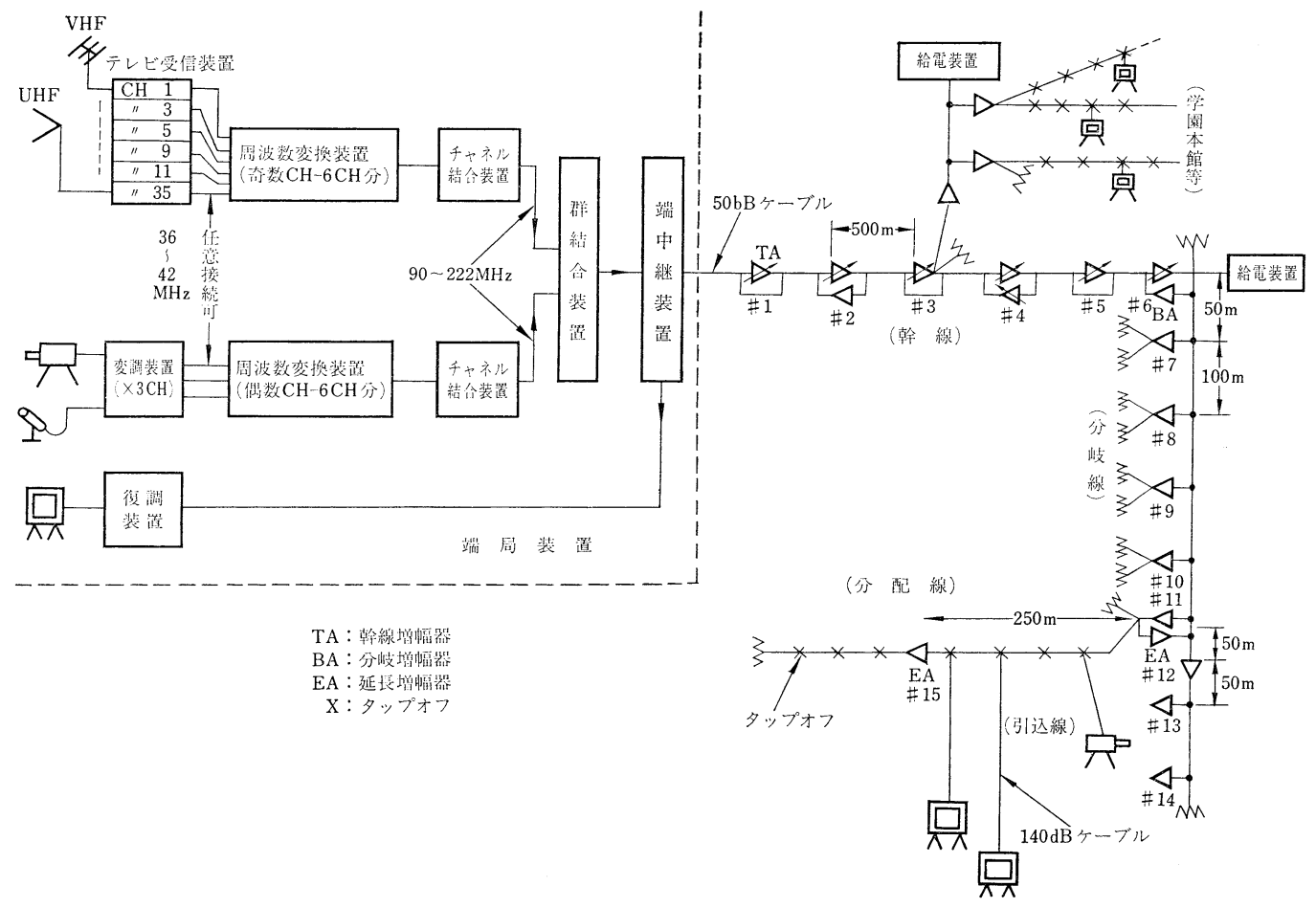

図 3 鈴鹿学園における CATV システム構成図 
䒾 3 CATV 施 設

\begin{tabular}{|c|c|c|c|c|c|c|c|c|c|c|}
\hline \multicolumn{2}{|l|}{ 施 } & 設 & \multirow[b]{2}{*}{$\begin{array}{l}\text { 運用開始日 } \\
\text { (年 月 日) }\end{array}$} & \multicolumn{3}{|c|}{ 目 } & \multicolumn{3}{|c|}{ 的 } & \multirow[b]{2}{*}{ サービス対象 } \\
\hline 名 称 & 所 在 地 & 所有団体 & & $\begin{array}{l}\text { 難 } \\
\text { 視 } \\
\text { 救 } \\
\text { 済 }\end{array}$ & $\begin{array}{l}\text { 自 } \\
\text { 主 } \\
\text { 放 } \\
\text { 送 }\end{array}$ & $\begin{array}{l}\text { 地 } \\
\text { 域 } \\
\text { 洅 } \\
\text { 逹 } \\
\text { 信 }\end{array}$ & $\begin{array}{l}\text { 情 } \\
\text { 報 } \\
\text { サ } \\
\text { । } \\
\text { ビ } \\
\text { ス }\end{array}$ & $\begin{array}{l}\text { 実 } \\
\text { 験 } \\
\end{array}$ & $\begin{array}{l}\text { そ } \\
\text { の } \\
\text { 他 }\end{array}$ & \\
\hline $\mathrm{A}$ & 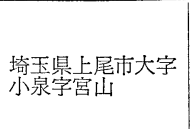 & 三井不動産 & $\begin{array}{l}\text { 46. } 8 \\
\text { (自主放送は, } \\
\text { 47年秋加らの予 } \\
\text { 定) }\end{array}$ & 0 & 0 & & 0 & & & 一般家庭 \\
\hline $\begin{array}{l}\text { B } \\
\text { 東京ケーブルビジ } \\
\text { ヨン(仮称) }\end{array}$ & $\begin{array}{l}\text { 横㴈市緑区 } \\
\text { 川踦市 }\end{array}$ & 東京急行 & $\begin{array}{l}\text { 49. } 4.11 \\
\text { (予 }{ }^{\text {定) }}\end{array}$ & & 0 & & O & & 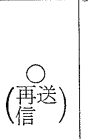 & $\begin{array}{l}\text { 一般家庭, 教育 } \\
\text { 機関 (幼稚園, } \\
\text { 小・中学校) }\end{array}$ \\
\hline 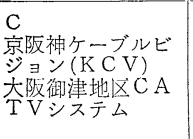 & $\begin{array}{l}\text { 大阪市東区法円坂 } \\
\text { 町 6-27 }\end{array}$ & $\begin{array}{l}\text { 財団法人京阪神ヶ } \\
\text { ーブルビジョシ }\end{array}$ & 45. 12. 22 & 0 & & & & 0 & & 一般家庭 \\
\hline 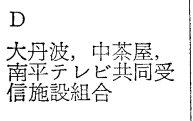 & 䙲多摩㴫 & $\begin{array}{l}\text { NHK拈よび施設 } \\
\text { 組合 }\end{array}$ & 46. 8. 1 & 0 & & & & & & 一般家庭 \\
\hline $\begin{array}{l}\mathrm{E} \\
\text { 境, 中山, 梅久保 } \\
\text { 設レビ共同受信施 } \\
\text { 組合 }\end{array}$ & 酉多糜郡奥多摩町 & \begin{tabular}{|l|} 
NHK捄よび施設 \\
組合
\end{tabular} & 46. 8. 20 & 0 & & & & & & 一般家庭 \\
\hline $\begin{array}{l}F \\
\text { 甲府C A T V局 } \\
(\mathrm{NNS})\end{array}$ & 岀梨県甲府市北口 & $\begin{array}{l}\text { 日本ネットワーク } \\
\text { サービス }\end{array}$ & 46. 10. 1 & 0 & 0 & 0 & 0 & $O$ & $\begin{array}{l}\text { ○ } \\
\text { レンタ } \\
\text { ルチャ } \\
\text { ネル }\end{array}$ & 一般家庭 \\
\hline $\begin{array}{l}\mathrm{G} \\
\text { 福岡ケーブルビジ } \\
\exists ソ(\mathrm{FCV})\end{array}$ & $\begin{array}{l}\text { 福岡市中洲 } 4 \text { 丁目 } \\
4 \text { 番10㤐 }\end{array}$ & 貝団法人福岡ケー & 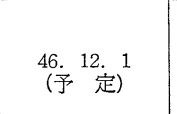 & 0 & & & & & & 一般家庭 \\
\hline 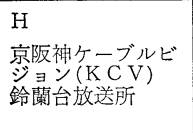 & $\begin{array}{l}\text { 神戸市兵庫区鈴蘭 } \\
\text { 台 }\end{array}$ & $\begin{array}{l}\text { 財団法人京阪神ケ } \\
\text {-ブルビジシ }\end{array}$ & $\begin{array}{l}\text { 46. } 10 \\
\text { (予 } \text { 定) }\end{array}$ & 0 & 0 & & & & & 一般家庭 \\
\hline $\begin{array}{l}\text { I } \\
\text { 下田有線テレビ放 } \\
\text { 送株式会社 }\end{array}$ & 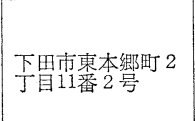 & \begin{tabular}{|l|} 
下田有線テレビ放 \\
送株式会社
\end{tabular} & 31. 8. 1 & & 0 & 0 & & & & 一般家庭 \\
\hline $\begin{array}{l}\mathrm{J} \\
\text { 東京ケーブルビジ } \\
\exists ン(\mathrm{TCV})\end{array}$ & 東京都新宿区三光 & 財団法人東京ケー & & 0 & & & & & & 一般家庭 \\
\hline $\mathrm{K}$ & 鈴鹿市白子町 & 䉓䉓公社 & 45. 11 & & & & & 0 & & \\
\hline
\end{tabular}


の現 状一覧

\begin{tabular}{|c|c|c|c|c|c|c|c|c|}
\hline 業 & 为 & 容 & & & & & & \\
\hline- & ᄌ & 内 & 容 & & & t & 入 & 数 \\
\hline 再送信および自 & 主 放 & & & & & 現 & 現加 & 計 \\
\hline 口再送信 $\mathrm{T} V$ & & $+ネ ル$ & & 上り回線 & サービス区域 & & $\begin{array}{l}\text { 在入 } \\
\text { 施可 }\end{array}$ & \\
\hline チャネル配列 $上$ 再送信 FM 【自主放送 & $\begin{array}{l}\mathrm{TV} \\
\text { 再送 }\end{array}$ & $\begin{array}{l}\mathrm{FM} \\
\text { 再送 } \\
\end{array}$ & 自主 & & & 在 & $\begin{array}{l}\text { 設能 } \\
\text { の数 }\end{array}$ & 画 \\
\hline 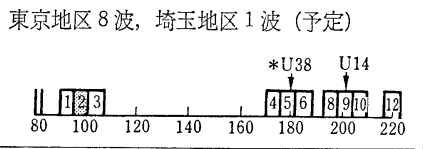 & 9 & 2 & 1 & & 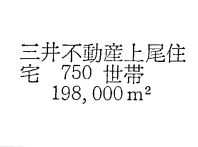 & 100 & 178 & 750 \\
\hline 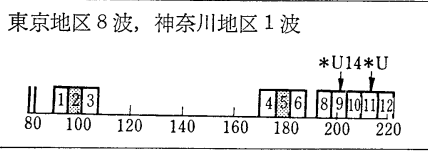 & 9 & 2 & 2 & $\begin{array}{l}42 \sim 48 \mathrm{MHz} \\
\text { (授業参観, ショ } \\
\text { ッピング報) }\end{array}$ & $\begin{array}{c}\text { 横浜, 川崎 } \\
3,400 \text { 世帯 } \\
1,550,000 \mathrm{~m}^{2}\end{array}$ & & & 3,000 \\
\hline 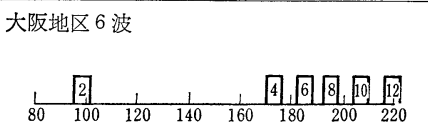 & 6 & & & & $\begin{array}{c}\text { 鰻谷, 西立町など } \\
850 \text { 世帯 } \\
180,000 \mathrm{~m}^{2}\end{array}$ & $\begin{array}{l}\text { 約 } 100 \\
\text { 端子 }\end{array}$ & $\begin{array}{l}\text { 約 } 400 \\
\text { 端子 }\end{array}$ & \\
\hline 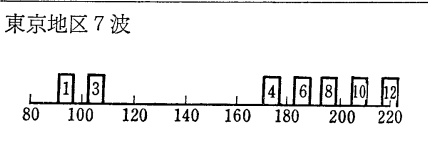 & 7 & & なし & な & $\begin{array}{l}\text { 大丹波地区など } \\
140 \text { 世帯 }\end{array}$ & 137 & & \\
\hline 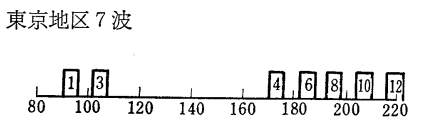 & 7 & & なし & し & $\begin{array}{l}\text { 境地区など } \\
48 \text { 世帯 }\end{array}$ & 48 & & \\
\hline 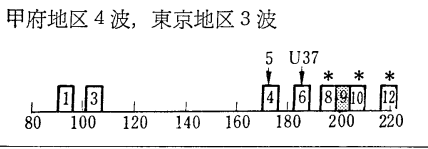 & 7 & & $\left(\begin{array}{c}1 \\
\left(\begin{array}{c}\text { 実験 } \\
\text { のみ }\end{array}\right)\end{array}\right.$ & $\begin{array}{l}36 \sim 42 \mathrm{MHz} \\
\text { (実験放送のみ) }\end{array}$ & $\begin{array}{r}\text { 甲府市一円 } \\
55,000 \text { 世帯 } \\
64 \mathrm{~km}^{2}\end{array}$ & 2,000 & 4,000 & 20,000 \\
\hline 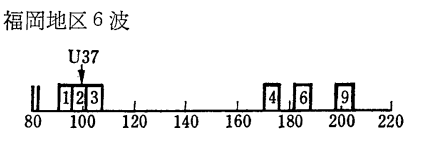 & 6 & 2 & & & $\begin{array}{c}\text { 福岡市 } 9,500 \text { 世帯 } \\
2.7 \mathrm{~km}^{2}\end{array}$ & 80 & & 3,000 \\
\hline 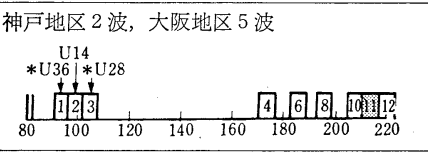 & 8 & 2 & $\stackrel{1}{1}$ & $10 \sim 30 \mathrm{MHz}$ & 鈴溗台 3,000世帯 & 工事中 & & 2,400 \\
\hline 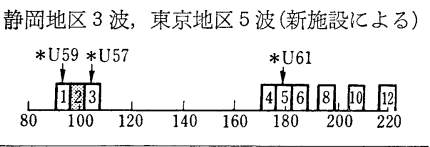 & 8 & & 1 & & $\begin{array}{c}\text { 下田市 } 4,500 \text { 世帯 } \\
6 \mathrm{~km}^{2}\end{array}$ & 4,500 & 5,000 & 5,000 \\
\hline 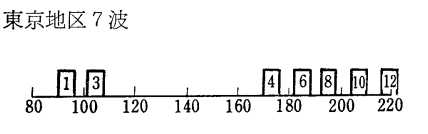 & 7 & & & & $\begin{array}{l}3,000 \text { 世帯 } \\
500,000 \mathrm{~m}^{2}\end{array}$ & 235 & 1,052 & \\
\hline 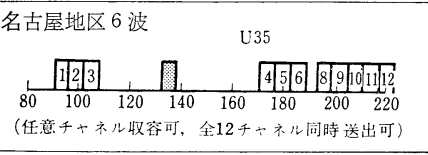 & 6 & & 2 & $26 \sim 60 \mathrm{MHz}$ & & & & \\
\hline
\end{tabular}


外再送信を目的とした下田，甲府等の施設 があり，またニュータウンに秥ける新しい 情報社会を目ざした埼玉県の上尾団地の設 備等がある. これら特徵のある設備概要の 一覧を表了に示す.

上記のうち電々公社が鈴鹿学園内に設置 した設備は，実験設備で営業を目的とした あのではないが，双方向性伝送を行なった わが国最初のもので，技術的にあ興味ある あのである. その系統を図 3 に示す.

\section{4. 海外における動き}

米国における CATV の規模は, 1971年 6月の NCTA の発表によれば, 1970年現 在の加入者数は約 590 万, 施設数は 2,150 であって, 農 村部 $23.3 \%$, 中小都市 $34.5 \%$, 大都市 $1.6 \%$ の普及率 となっている ${ }^{9)}$. 米国に扣いてはより多くの放送番組を みたいという要求に応えての施設が多く, まだ多チャネ ル放送のある大都市に㧧ける普及率は小さい.

技術的にみると，システム構成は大部分わが国で考え られているものと大差はない. しかし, 機器はマーケッ トの大きいことああり，CATV 専用のあのが測定器を 含めて多く売り出されている. システム的に見て特幑あ るあのの 1,2 を次に述へる.

(1) AML システム ${ }^{10) 11}$

CATV の幹線を長距離に敷くには，技術的要求も厳 しくなり経済的にあ高くなる．乙のため $12 \mathrm{GHz}$ 帯の電 波で多くのへッドェンド向けに番組を中継しようとする むので, 通常のマイクロ波通信と異なる点は, 振幅変調 を用いて周波数の経済化，ヘッドェンドに括ける变復調 の簡便化をはかっている点にある.ニューヨークにおい ては 1971 年秋頃より運用されているという.

(2) Dial-a-Program システム ${ }^{12}$

英国の Rediffusion 社の開発したシステムであって, 図 4 に示すように幹線は同軸ケーブルで伝送するが，分 岐線以降は 2 対のペアケーブルを各加入者ごとに設けて いる．乙の分岐点にはスイッチが設けられており，各加 入者端末に設けられている電話器のダイヤルのようなチ ヤネルセレクターを回すととにより符号がスイッチに送 られ，希望する番組が選択され，ペアケーブルで加入者 に送られる，乙の方式はチャネル数が多くなるほど経済 的になるといわれている. 1970 年 10 月より小規模なフ

トランク線路 受像機

加入者端末

図 4 Dial-a-Program システムの分配系 ィールド試験が行なわれている.

(3) 双方向システム ${ }^{12}$

上記 Dial-a-Program システムむ双方向システムであ るが，スイッチングを使用しないで双方问機能を持たせ るととができる. CATV の将来の発展, 有線都市を目 ざして多くの研究がなされている，たとえば，音声，ビ デオ，データの返送機能をもったVicom，加入者のデー 夕応答を求める SRS, 静止画像をもって加入者からの要 求に応えて情報を送る TICCIT 等, 種々のシステムが あり，1971 年頃より実際のフィールドに执いて技術実 験屯各地で行なわれるようになった，しかし，まだきわ めて小規模の純技術的な実験の域を出ず，サービス試験 を行なう段階には至っていない模様である.

\section{〔参考 文 献〕}

1) 電波技術協会: 有線テレビジョン技術調查委員会調查報告書 (1969. 12)

2) FCC Rule \& Regulation $\$ 76.605$ (1972.2 公布)

3) Technical Standard and Procedures for Cable Television Systems，カナダ通信省 (1971.3 公布)

4) IEC 文書, $12 \mathrm{~A}(\mathrm{~S}) 133$ (1971.3)

5） CCIS サービスの需要動向調査について，郵政省報道資料（1972. 1.27)

6) 東京ケーブルビジョン, 白水総務より私信

7) 地域情報化システム調査委員会中間報告書, 技術調査委員会 (I), 電振協 (1972.1)

8）陸川ほか：CATV 方式について，電通施設，23，4 (1971)

9）アメリカ, カナダの CATV (視察報告), 国際産業促進センター (1971)

10) F. Ivanek: An All Solid-State SSB-AM Microwave System for Multichannel TV Transmission in the $12.7 \sim 12.95 \mathrm{GHz}$ Cars Band, Microwave Journal, Nov. (1971) 46

11) THETA-COM 社パンフレット "AML"

12) R.K. Jurgen: Two-Way Applications for Cable Television Systems in the '70, IEEE Spectrum, Nov. (1971) 39 